\title{
RESEARCH ON ATTITUDES AND PREFERENCES OF TOURISTS IN THE CITY OF BRASOV ON THE INTRODUCTION OF HYBRID TRANSPORTATION SYSTEMS
}

\author{
Constantinescu Laurențiu ${ }^{7}$
}

\begin{abstract}
The research refers to the attitudes and preferences of Brasovian's regarding the introduction of hybrid transport systems. Other studies carried out on this topic have helped us to understand the attitude and preferences of Brasovians when it comes to hybrid transport systems. These hybrid transport systems They are based on environmental assessment and meeting the needs of customers who call for these public transport services. The hypotheses are specific to the qualitative research, the formulation is made after the research goals have been defined and the conception with which we will work. The assumptions from which we started are that these hybrid systems have a good impact on the environment. The fact that the technology of hybrid vehicles or all electrics are gaining more ground in recent years. The research is of a qualitative type based on a questionnaire, carried out on a total number of subjects taking place in Brasov. Following the initiation of the questionnaire, we managed to reach the following conclusions, where more than half of our respondents consider that these hybrid transport systems make us - they would be very beneficial and at the same time would have been used by the tourists of Brasov, thinking about protecting the environment. Due to the fact that Brasov is a mountain town with high levels of extremely low temperatures during the winter, I thought that the first step to reduce pollution is the introduction of these hybrid transport systems. Hybrid buses have a low fuel consumption, saving about $30 \%$ of the fuel requirement of a normal diesel bus. Brasovians and tourists from the city of Brasov regarding these transport systems. In short, this art icol represents a good development and vision on Brasov as well as a good vision from the residents and those who visit Brasov
\end{abstract}

Key words: Reserch on Brasov, Systems transport of hybrid, attitudes and preferences , qualitative research.

\section{INTRODUCTION}

The overall purpose of this project is to conduct research on the benefits of air quality of electric vehicles as a means to help manage air quality in communities.

The impact of air quality is estimated the annual Community emissions at the level of:

- Greenhouse gases - carbon dioxide, methane, nitrogen oxide

- Local atmospheric pollutants - carbon monoxide, nitrogen oxides, volatile organic compounds, suspended sulfite oxides

\footnotetext{
${ }^{7}$ Faculty of Food and Tourism, Transilvania University of Brașov, 29 Eroilor Boulevard, 500036, Brașov, Romania, constantinescu.laurentiu90@yahoo.com.
} 
Hybrid or fully electric vehicle technology is gaining more and more ground in recent years. Although hybrid buses make up $20 \%$ of the market in North America, interest in Europe is much lower, but it is still on an upward trend

"Tourism, whose spectacular growth is expected to continue, now accounts for $8 \%$ of greenhouse gas emissions and is increasingly influencing climate change, something that had not been estimated so far, according to a study published Monday." (Babici, CLC, 2012)

\section{Public transport shifts to hybrid vehicles}

Marketing research concerns the process of investigation, collection, filtering, processing, analysis, interpretation, exploitation and dissemination of information, which describes a marketing situation, in order to substantiate a decision. Marketing research finds the shortest path to the customer and reduces the risk of decisions.

The present research is a study carried out on a sample of locals, based on a questionnaire, a case study drawn up with the purpose of identifying the attitude and introducing hybrid transport systems in Brasov City. one year .

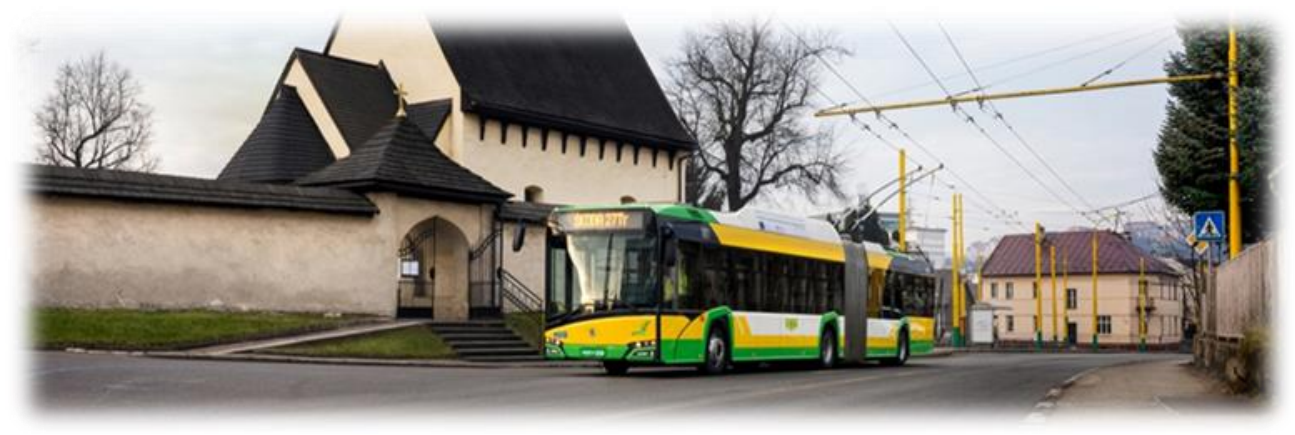

Fig.1 . Hybrid Bus

The first 26 Solaris trolleybuses will be supplied to the municipality of Brasov within a maximum of one year, the mayor George Scripcaru and the representative of the Polish company signing, on July 1, their purchase contract, worth over 90 million lei. 18 have a capacity of 130 passengers, of which 40 on seats, and have a battery that allows them autonomy up to a minimum of 5 kilometers, so that they will also serve portions of the route that are not equipped with electric cable. The 26 vehicles will serve 4 lines (1, 2, 6 and 31) that are not 100\% electrified and for which, when they cross the central area of the city, there is a need to reduce pollution. The buses will be equipped with an information system of passengers, GPS tracking, air conditioning (two units for passengers and one for driver), two displays for ads and advertisements, four validators, USB sockets for charging electronic devices, wifi .. (https://brasovromania.net.) 


\section{RESEARCH METHODOLOGY}

Marketing research concerns the process of investigation, collection, filtering, processing, analysis, interpretation, exploitation and dissemination of information, which describes a marketing situation, in order to substantiate a decision. Marketing research finds the shortest path to the customer and reduces the risk of decisions.

The present research is a study carried out on a sample of locals, based on a questionnaire, a case study drawn up with the purpose of identifying the attitude and introducing hybrid transport systems in Brasov City.

Tab. 1. Questionnaire and research methodology

\begin{tabular}{|c|c|c|}
\hline Basic aspects & Researcher's questions & Researcher's objectives \\
\hline $\begin{array}{c}\text { 1.If the introduction } \\
\text { of hybrid transport } \\
\text { systems in intelligent } \\
\text { urban transport is } \\
\text { known and accepted. }\end{array}$ & $\begin{array}{c}\text { 1. To what extent do } \\
\text { consumers know about } \\
\text { the intelligent urban } \\
\text { transport system? }\end{array}$ & $\begin{array}{c}\text { 1.Determining the extent to } \\
\text { which consumers know about } \\
\text { the electric transport systes . }\end{array}$ \\
\hline $\begin{array}{c}\text { 2. Consumer } \\
\text { preference for hybrid } \\
\text { technology for urban } \\
\text { transport vehicles. }\end{array}$ & $\begin{array}{c}\text { 2. What is the attitude of } \\
\text { consumers in relation to } \\
\text { electric transport? }\end{array}$ & $\begin{array}{c}\text { 2. Identify the reasons that the } \\
\text { electric transmission system is } \\
\text { efficient. }\end{array}$ \\
\hline $\begin{array}{c}\text { 3.Identifying the } \\
\text { attitudes of } \\
\text { consumers regarding } \\
\text { the introduction of } \\
\text { hybrid transport } \\
\text { systems. }\end{array}$ & $\begin{array}{c}\text { 3.Which variants are } \\
\text { more electric or diesel } \\
\text { preferred? }\end{array}$ & $\begin{array}{c}\text { 3. Identification of the } \\
\text { categories of consumers by age, } \\
\text { sex, profession, income. }\end{array}$ \\
\hline
\end{tabular}

\section{RESEARCH HYPOTHESES}

The hypotheses are specific to quantitative research; their formulation is made after the research goals and concepts we will work with have been defined.

There are a number of reasons why assumptions are necessary:

(1) the necessity of determining and delimiting the research field;

(2) a hypothesis guides the data collection, analysis and interpretation.

In most cases, the hypotheses refer to the verification of relations that are established between two variables, which allows us to say that the respective hypothesis contains a possible solution to the problem under study. In essence, the hypothesis is an 
unproven affirmative or negative proposition. , regarding a factor or phenomenon that is of interest to the researcher. It is an anticipation of the answers to the investigated problem. It is a precise sentence, which can be tested and possibly accepted, based on the data collected. Sometimes the hypothesis can be a statement about the relationship between two or more variables of the research. According to him (S. Chelcea, 2001), the hypotheses must meet 10 conditions to be valid: generality, complexity, specificity, determination, falsifiability, testability, predictability, communicability, reproducibility and usefulness (Neacşu, Niculescu, Rus, 2000)

The research method is:

The sociological inquiry based on the questionnaire will be used in this research. The present research is a quantitative research based on a questionnaire, carried out on a total number of 56 subjects, taking place during June 2019, in the city of Brasov. Given the research objectives, the group of subjects targeted a batch of 100 subjects, the answers being received from 56 subjects.

\section{Sample presentation}

One of the most important problems to be solved, in almost all cases, the one designing an investigation is the one related to sampling or selection. These subjects designate a set of operations with which from the entire population targeted by the research, a part called sample is chosen, part that will be directly submitted to the investigation. This does not mean that the universe of research is reduced, only that the necessary information is not collected from all individuals, but only from some of them. The choice must be made in such a way that, through this small study, conclusions with general validity can be drawn. The choice of a sample is used in situations where the population is large and it is not possible, nor efficient to study in its entirety.

Based on statistical principles, a subpopulation can be successfully chosen to supplement the research of the entire population. The determined sample will be the basis of the application of the questionnaire - the instrument by which data collection is carried out in surveys. The preparation of the questionnaire is an extremely difficult operation. Probably an ordinary person did not care about this program; After all, any normal person can imagine 10-20 questions on a given topic. But the secret is that the questionnaire is not just a series of questions elaborated on the principle "let's see what is answered". Each question must be a valid indicator of a dimension of the problem investigated, and their chain is not one at will. 
The success of a research lies, in addition to the promptness of the questionnaire, in the requirement that the sample possess an essential quality - representativeness, which consists in the ability to reproduce as accurately as possible the structures and characteristics of the population from which it is extracted. Sampling is the process of selecting a part of a statistical universe that is of interest to decision makers, in order to draw conclusions about the parameters of the entire studied universe.

The technique used is the questionnaire to identify and analyze the perceptions, attitudes and expectations of the interviewees. This is a technique through questions and answers, in order to obtain information from the interviewees in order to prove the research questions.

\section{CONCLUSION AND PROPOSALS}

Due to the fact that Brasov is a mountain town with high level differences and extremely low temperatures during the winter, I think the first step to reduce pollution through efficient and public transport is the use of hybrid buses instead of electric ones. Hybrid buses have low fuel consumption, saving about 30 percent of the fuel requirement of a normal diesel bus.

The Bucharest City Hall has already launched the tender for the purchase of 100 electric buses, planning to purchase the necessary infrastructure for their charging.

Cluj-Napoca City Hall will buy 30 electric buses, worth about 500,000 euros each, these being equipped with wi-fi, video cameras, air conditioning and the low platform for people with disabilities. The first buses will be delivered by March 2018 at the latest. According to the mayor of Cluj, the money for these buses comes from Swiss funds (85\%) and local budget (15\%).

In Sibiu, the urban mobility plan also includes the presence of electric buses. The City Hall of Sibiu will renew its fleet of buses with electric models that will be bought through a bank loan, having a value of 12 million Euros, ie about 55 million lei, with a repayment period of 10 years. 


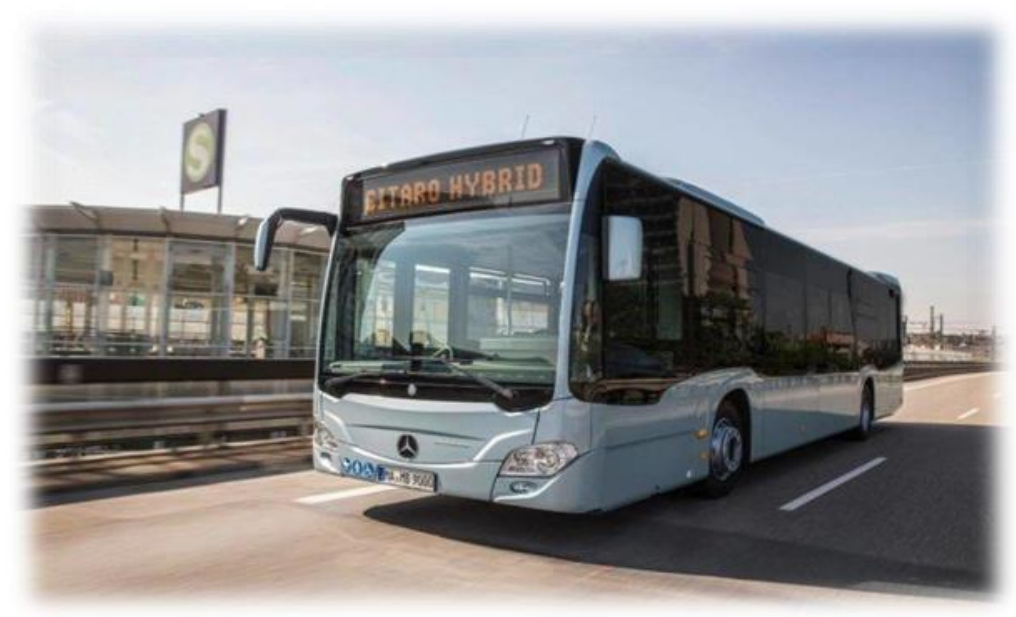

Fig.2. Citaro hybrid bus

\section{REFERENCES}

1. Babici, C.L.C. (2012). Strategii de control pentru autovehicule electrice hibride“, Teză de Doctorat,Universitatea Tehnică Gheorghe Asachi, Iași.

2. Burnete, N., ș.a. (2008). Motoare Diesel și Biocombustibili pentru transportul urban", EdituraMediamira, Cluj-Napoca.

3. Cristescu, C. (2009). Sistemele hibride de propulsie a autovehiculelor urbane soluţii pentru reducerea agresiunii asupra mediului şi diminuarea consumului de combustibil, Buletinul AGIR.

4. Draica C. (1999). Ghid practic de turism internaţional şi intern, Editura All Beck, Bucureşti.

5. Ehsani, M., Gao, Y., Gay, S.E. (2005). Modern Electric, Hybrid Electric, and Fuel Cell Vehicles, Fundamentals, Theory, and Design, CRC Press Ed., 2005, ISBN 0-8493-3154-4;

6. Glăvan, V. (2012). Turismul de România, Editura Economica, Bucureşti.

7. Ioța, C. (2012). Bosch - Tehnologie şi know-how pentru autovehiculele hibride, Ingineria Automobilului,Vol. 6, Nr. 1.

8. Croitoru, M. (2011). Indicele competitivităţii în turism - analiză empirică România vs. Bulgaria, Economie teoretică şi aplicată XVIII, 9(562), Bucureşti, pp. 110-128,

9. Neacşu N., Niculescu G., Rus F. (2000). Turismul şi dezvoltarea durabilă , Editura Expert, Bucureşti.

10. Annals of Cercetare Turism, The Pembina Institute, Clean Air Benefits from Electric Vehicles 
Internet sources

https://trans.info/ro/transportul-comun-vireaza-catre-vehicule-hibride-68557

http://www.rasfoiesc.com/business/transporturi/Utilizarea-sistemelor-hibride-24.php

https://www.eea.europa.eu/ro/articles/vehiculele-electrice-un-pas-inainte

https://www.still.ro/tehnologie-hibrida.0.0.html

https://www.notabn.ro/primaria-brasov-a-semnat-azi-primul-contract-de-achizitie-

mijloace-de-transport-electrice-si-hibride/

https://brasovromania.net/2018/08/foto-video-brasov-autobuz-hibrid-in-teste-la-ratbv-

cristian-macedonschi-datorita-faptului-ca-brasovul-este/

http://www.edumark.ase.ro/RePEc/rmko/4/10.pdf 